\title{
Preliminary assessment of trace metals and polycyclic aromatic hydrocarbons in the sediments
}

\author{
E.C. Okafor, "K. Opuene \\ Department of Pure and Industrial Chemistry, Faculty of Physical Sciences, University of Nigeria, Nsukka, Nigeria
}

Received 10 June 2006; revised 28 February 2007; accepted 11 March 2007; $\quad$ available online 20 March 2007

\begin{abstract}
Total concentrations of $\mathrm{Cd}, \mathrm{Cr}, \mathrm{Co}, \mathrm{Fe}, \mathrm{Pb}, \mathrm{Ni}, \mathrm{Mn}$ and $\mathrm{Zn}$ were determined by atomic absorption spectrophotometry in the surface sediments of Taylor Creek, Southern Nigeria. The most concentrated trace metals, ranging from 113.2 to $5160.7 \mathrm{mg} / \mathrm{g}$-dry weights were $\mathrm{Fe}, \mathrm{Pb}, \mathrm{Mn}, \mathrm{Ni}$ and $\mathrm{Zn}$. There was no significant variation in sediment-associated metal levels ( $>0.05$ ). The Metal Pollution Index (MPI) was highest at Agbia/Nedugo and is attributed to local contamination of the Creek. The concentrations of low molecular weight polycyclic aromatic hydrocarbons (PAHs) were also detected and quantified in the sediments by capillary gas chromatography equipped with a flame ionization detector. The concentration levels of $178.1-1266.3 \mathrm{mg} / \mathrm{g}$-wet weights were high for the PAHs. The results indicate that the pollutants, which are bio-accumulatable, could contribute to inferior biodiversity, and shifts in community composition from sensitive to tolerant taxa.
\end{abstract}

Key words: Trace metals, polycyclic aromatic hydrocarbons, sediments, Taylor Creek

\section{INTRODUCTION}

Sediments embody the critical elements of freshwater ecosystems. Overwhelming evidence from many sources had indicated that human activities have significant and far-reaching impacts on the sediments of freshwater ecosystems (Nriagu, 1996).

Contamination of aquatic ecosystems by noxious waste indicators such as trace metals and polycyclic aromatic hydrocarbons (PAHs) is a problem in society because the environment is often used as a receptacle for waste products generated in the economy. Sediments, in general, have been employed to monitor the pollution of aquatic environments for the reason that trace metals and PAHs generally existing in low concentration levels in the water column have a propensity to associate preferentially with the sediments and attain considerable concentration (Fortner and Wittmann, 1983; German Ministry of Environment, 1993).

Trace metal contaminated sediments therefore represent significant environmental concern as such sediments have been demonstrated to be toxic to sediment-dwelling organisms and fish resulting in decreased survival, reduced growth, or impaired reproduction, and lower species diversity (La Point, et *Corresponding author, Email: opuenekings@yahoo.com Tel./Fax: +234 8038916768 al., 1984, Clements, 1991). Specifically, the presence of polycyclic aromatic hydrocarbons (PAHs) could produce cancer-like growths and are teratogenic and mutagenic to fishes, which may result in a fibrosarcoma and a stomach papilloma, along with tumours (Hendricks, et al., 1985).

The primary purpose of this study was to report the concentration levels and spatial distribution of selected trace metals and low molecular weight polycyclic aromatic hydrocarbons (PAHs) in the sediments of Taylor Creek, where several oil spills resulting from oil industry operations had occurred.

\section{MATERIALS AND METHODS}

Geographic setting and sampling sites

The study area had previously been described (Okafor and Opuene, 2006) and is presented in Fig. 1. Taylor Creek is a non-tidal freshwater ecological unit located in Gbarain clan in the Yenagoa Local Government Area of Bayelsa State. Southern Nigeria. The Creek is $16 \mathrm{~km}$ and on North-northeast (NNE) from the state capital of Bayelsa state. Taylor Creek has a high proportion of watersheds and very intense rural settlements distributed along its stem. There are subsistent agricultural lands and typical freshwater and swampy rain forests in the region. 
The region enjoys the humid tropical climate characterized by the hot and wet conditions associated with the movement of the Inter-Tropical Convergence Zone (ITCZ) north and south of the equator and experiences consistently high temperatures (about ${ }^{\circ} \mathrm{C}$ ) all year round. Since temperature varies only slightly, rainfall distribution, over space and time, becomes a single most important factor. The implication is that there is a prolonged rainy season in the region. The study environment, therefore, has two major seasons, the dry season and the wet season.

The only perceptible activity of economic worth in the region is oil industry activities. The Etelebou Flow Station, which is located on a second order distributary, discharges liquid effluents into the tributary of Taylor Creek (Fig. 1). As a result, five sampling sites were established along Taylor Creek: Site 1 (Agbia/Nedugo, $\left.06^{\circ} 19^{\mathrm{I}} / 05^{\circ} 03^{\mathrm{I}}\right)$, Site 2 (Ogboloma, $\left.06^{\circ} 20^{\mathrm{I}} / 05^{\circ} 03^{\mathrm{I}}\right)$, Site 3

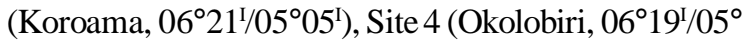
$02^{\mathrm{I}}$ ) and Site 5 (Polaku, $\left.06^{\circ} 17^{\mathrm{I}} / 05^{\circ} 01^{\mathrm{I}}\right)$.

Field collection of surficial sediment, sample preparation and analysis

Surface sediments were collected monthly from each of the five sampling sites in the period January 2003 to September 2004 by the grab method using an Eckman grab sampler on 3 to 4 locations, representing approximately $2-3 \mathrm{~cm}$ of surface sediments, within each sampling site, and wrapped with aluminum foil to avoid contamination, frozen and taken to the laboratory.

Individual site (sediment) sample was thawed and dried at $85^{\circ} \mathrm{C}$ and pulverized to $<50 \mathrm{~mm}$ using a shatterbox grinding mill (Anonymous, 1990). In order to avoid interference of organic matter in the results and convert the metals to their free form, sub-samples ( $2 \mathrm{~g}$ ) of ovendried sediment were moistened with water and put into a $50 \mathrm{~mL}$ conical flask and $10 \mathrm{~mL}$ of conc. nitric acid and $2 \mathrm{ml}$ of conc. perchloric acid were added and digested by a microwave (CEM, MDS, 2100) in a closed fluorocarbon vessel. The digestion process was optimal to digest organic matter with associated metals so as to extract metals linked by adsorption to the sediments, which together represent bioavailable or leachable metals of the surface sediments. The solution was allowed to cool and subsequently filtered into a $50 \mathrm{~mL}$ volumetric flask. Following acid digestion, all samples were analyzed for 8 elements by flame atomic absorption Spectrophotometry (using Buck Scientific Model 200A Spectrophotometer, equipped with a high sensitivity nebulizer). Hollow cathode lamps for $\mathrm{Cd}, \mathrm{Co}, \mathrm{Cr}, \mathrm{Pb}, \mathrm{Ni}$, $\mathrm{Mn}, \mathrm{Zn}$ and Fe were employed following the manufacturer's recommendations. Calibration of Buck Scientific Model 200A Spectrophotometer was performed before every run by successive dilution of a 100 mg/L Multi-Element Instrument

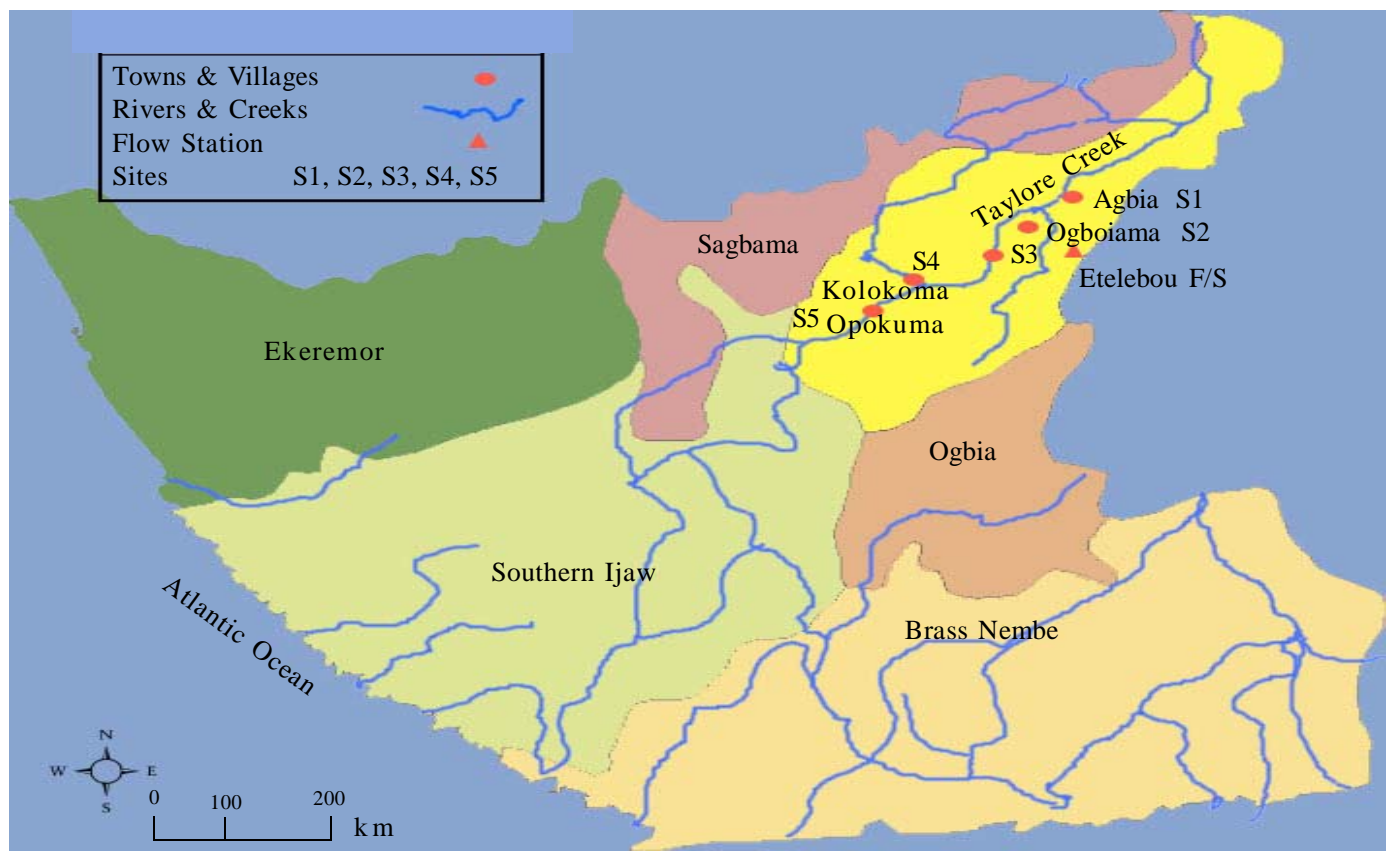

Fig. 1: Study location and sampling site map 
Calibration Standard solution (Fisher Scientific) that was in a range covering the concentration levels in the analyzed samples.

For each batch of elemental analysis, intra-run quality insurance standard (1 mg/L, Multi-Element Standard Solution, Fisher Scientific) was checked for reading deviation and accuracy of every 10 samples.

Internal blanks were used to assess any background contamination originating from sample manipulation and preparation. Blanks were processed exactly as respective regular samples. Accuracy of sample manipulation was checked using samples of PACS-2 (sediment) Matrix Certified Reference Materials with known concentration for certain metals (Cantillo and Calder, 1990).

Field collection of surface sediments and sample preparation for GC-FID analysis

Samples of surface sediments were also collected opportunely on quarterly basis in the period January 2003 to June 2004 in conformity with high-quality sampling techniques.
The experimental procedure as described by Muniz, et al. (2004) was cautiously followed. Polycyclic Aromatic Hydrocarbons were extracted from the surface sediments by Soxhlet extraction with dichloromethane. The extracts were further purified (to deny interferences by aliphatic hydrocarbons, porphrins, chlorins, and carotenoids, if present in the prepared matrices). The empirical purification entailed the use of neutral activity I alumina as an adsorbent. It was introduced in slurry form with hexane into $1 \mathrm{~cm}$ glass columns to a depth of about $10 \mathrm{~cm}$. Concentrated extracts were dissolved in hexane and subsequently introduced to the wet adsorbent and eluted with this solvent to remove aliphatic hydrocarbons. A second eluant was benzene, which removed the aromatic materials with sufficient purity for the Capillary GCFID analysis. The purified aromatics were analyzed by a calibrated capillary GC-FID using an HP 6890 Series GC system equipped with Flame Ionization Detector. The column used was a HP-5, $30 \mathrm{~m}$ X $0.25 \mathrm{~mm}$ X 0.25mm (HP Part No. 19091S-433). Hydrogen (10.2 psi) was used as carrier gas at $1.5 \mathrm{~mL} / \mathrm{min}$.

Table 1: Measurement accuracy of standard material (PACS-2)

\begin{tabular}{llllll}
\hline \multicolumn{1}{c}{ Value type } & $\mathrm{Cd}$ & $\mathrm{Cr}$ & $\mathrm{Pb}$ & $\mathrm{Ni}$ & $3 \mathrm{Zn}$ \\
\hline Certified Value & 1.000 & 90.7 & 183 & 39.5 & $37.4(2.1)$ \\
Measured Value & $0.770(0.13)$ & $86.3(4.40)$ & $174(9.00)$ & $340(24)$ \\
Recovery & $87 \%$ & $94.38 \%$ & $95.08 \%$ & $94.68 \%$ & $93.41 \%$ \\
\hline
\end{tabular}

*The values in parentheses are standard deviations (SD).

Table 2: Mean concentrations of trace metals ( $\mu \mathrm{g} / \mathrm{g}$ dry weight) in sediments

\begin{tabular}{|c|c|c|c|c|c|}
\hline \multirow{2}{*}{ Parameter } & \multicolumn{5}{|c|}{ Sampling sites } \\
\hline & 1 & 2 & 3 & 4 & 5 \\
\hline \multicolumn{6}{|c|}{ Sediments } \\
\hline \multirow{3}{*}{$\mathrm{Cd}$} & $10.90-0.600$ & $10.45-1.200$ & $10.45-0.440$ & $11.36-0.44$ & $12.20-0.600$ \\
\hline & $(2.870 \pm 2.599)$ & $(3.360 \pm 2.494)$ & $(2.970 \pm 2.460)$ & $(2.961 \pm 2.591)$ & $(3.010 \pm 2.900)$ \\
\hline & 16.00-BDL & 16.00-BDL & 16.40-BDL & 11.00-BDL & 10.00-BDL \\
\hline \multirow{2}{*}{$\mathrm{Cr}$} & $(3.233 \pm 4.467)$ & $(2.998 \pm 4.009)$ & $(3.710 \pm 4.800)$ & $(2.913 \pm 4.000)$ & $(2.260 \pm 3.070)$ \\
\hline & 1000.5-1.00 & $1020.3-2.400$ & 1121.2-4.200 & $1170.2-6.200$ & 1061.1-6.200 \\
\hline \multirow[t]{2}{*}{$\mathrm{Pb}$} & $(115.16 \pm 251.3)$ & $(115.18 \pm 255.9)$ & $(122.02 \pm 281.3)$ & $(126.5 \pm 293.7)$ & $(119.3 \pm 266.3)$ \\
\hline & $27.00-2.800$ & $22.00-3.400$ & $22.00-4.00$ & $19.50-4.600$ & $24.50-5.200$ \\
\hline \multirow[t]{2}{*}{ Co } & $(10.13 \pm 6.88)$ & $(8.333 \pm 6.483)$ & $(8.56 \pm 5.59)$ & $(10.11 \pm 4.92)$ & $(10.06 \pm 6.41)$ \\
\hline & $34.00-3.00$ & $26.50-2.00$ & $27.50-3.200$ & $28.50-2.400$ & $28.500-3.200$ \\
\hline \multirow[t]{2}{*}{$\mathrm{Ni}$} & $(10.18 \pm 8.732)$ & $(9.050 \pm 7.530)$ & $(8.530 \pm 6.330)$ & $(9.137 \pm 6.918)$ & $(8.515 \pm 6.34)$ \\
\hline & $5204.0-5080.0$ & $5204.0-5125.0$ & $5220.0-5110.0$ & $5212.0-5104.0$ & $5216.0-5125.0$ \\
\hline \multirow[t]{2}{*}{$\mathrm{Fe}$} & $(5148.0 \pm 49.90)$ & $(5155.7 \pm 31.07)$ & $(5168.8 \pm 52.46)$ & $(5161.3 \pm 46.48)$ & $(5169.7 \pm 44.85)$ \\
\hline & $1300.0-50.88$ & $475.00-14.28$ & 490.5-12.12 & 531.3-23.04 & $624.8-12.24$ \\
\hline \multirow[t]{2}{*}{ Mn } & $(266.92 \pm 287.22)$ & $(177.51 \pm 115.4)$ & $(184.58 \pm 95.27)$ & $(214.21 \pm 114.19)$ & $(256.64 \pm 159.7)$ \\
\hline & $279.0-9.70$ & 284.8-19.88 & $283.2-20.53$ & $301.40-16.05$ & 285.6-13.15 \\
\hline $\mathrm{Zn}$ & $(107.73 \pm 98.61)$ & $(118.68 \pm 109.71)$ & $(108.25 \pm 103.7)$ & $(117.62 \pm 108.84)$ & $(113.51 \pm 107.1)$ \\
\hline
\end{tabular}


Preliminary assessment of trace metals and polycyclic aromatic hydrocarbons in the...

Table 3: Mean concentrations of PAHs ( $\mu \mathrm{g} / \mathrm{g}$ wet weight) in sediments

\begin{tabular}{|c|c|c|c|c|c|}
\hline \multirow[t]{2}{*}{ Parameter } & \multicolumn{5}{|c|}{ Sampling Sites } \\
\hline & 1 & 2 & 3 & 4 & 5 \\
\hline \multirow{3}{*}{ 2-Methylnaphthalene } & $0.199-0.180$ & $0.203-0.183$ & $0.205-0.180$ & $0.201-0.180$ & $0.205-0.184$ \\
\hline & $(0.184-0.0073)$ & $(0.1877-0.0076)$ & $(0.1860-0.0084)$ & $(0.1891-0.0076)$ & $(0.1887-0.0076)$ \\
\hline & $0.192-0.171$ & $0.194-0.175$ & $0.193-0.175$ & $0.193-0.175$ & $0.192-0.172$ \\
\hline \multirow{2}{*}{$\begin{array}{l}\text { Acena- } \\
\text { phthylene }\end{array}$} & $(0.1772-0.0076)$ & $(0.1793-0.0074)$ & $(0.1784-0.0072)$ & $(0.1780-0.0077)$ & $(0.1775-0.0074)$ \\
\hline & $0.190-0.172$ & $0.193-0.175$ & $0.191-0.171$ & $0.190-0.171$ & $0.188-0.171$ \\
\hline \multirow[t]{2}{*}{ Fluorene } & $(0.1756-0.0071)$ & $(0.1782-0.0075)$ & $(0.1760-0.0074)$ & $(0.1760-0.0072)$ & (0.1740-0.0073) \\
\hline & $0.574-0.520$ & $0.575-0.521$ & $0.575-0.521$ & $0.573-0.521$ & $0.575-0.521$ \\
\hline \multirow[t]{2}{*}{ Phenanthrene } & $(0.5312-0.0211)$ & $(0.5321-0.0212)$ & $(0.5322-0.0211)$ & $(0.5304-0.0210)$ & $(0.5315-0.0214)$ \\
\hline & $1.591-0.146$ & $1.61-0.146$ & $1.610-0.146$ & $1.61-0.146$ & $1.61-0.146$ \\
\hline \multirow[t]{2}{*}{ Anthracene } & $(1.255-0.546)$ & $(1.270-0.554)$ & $(1.266-0.552)$ & $(1.2701-0.554)$ & $(1.270-0.554)$ \\
\hline & $0.434-0.39$ & $0.437-0.395$ & $0.437-0.3953$ & $0.434-0.394$ & $0.434-0.395$ \\
\hline $\begin{array}{l}\text { Fluora- } \\
\text { nthene }\end{array}$ & $(0.3988-0.015)$ & $(0.4039-0.016)$ & $(0.4039-0.016)$ & $(0.4016-0.016)$ & $(0.4039-0.016)$ \\
\hline
\end{tabular}

The column was kept at $80^{\circ} \mathrm{C}(1 \mathrm{~min}), 20^{\circ} \mathrm{C} / \mathrm{min} 280^{\circ} \mathrm{C}$, $2.5^{\circ} \mathrm{C} / \mathrm{min}, 300^{\circ} \mathrm{C}(4 \mathrm{~min})$. The temperature of the FID and $\mathrm{T}_{\mathrm{ij}}(1 \mathrm{~mL}, 0.01 \mathrm{mg}$ each/mL, split 25/1) was kept at $325^{\circ} \mathrm{C}$. Quantification was performed using internal standards. Quality assurance was by the analysis of a certified reference material (NIST-1941).

Metal /PAHs pollution index

To compare the total content of metals at the different sampling sites, the Metal Pollution Index (MPI) was used. The MPI was obtained with the equation (AMA, 1992; Usero, et al., 1996):

MPI $=\left(\mathrm{Cf}_{1} \mathrm{X} \mathrm{Cf}_{2} \ldots \ldots \ldots \mathrm{Cf}_{\mathrm{K}}\right)^{1 / \mathrm{K}}$,

Where;

$\mathrm{Cf}_{1}=$ concentration value of the first metal.

$\mathrm{Cf}_{2}=$ concentration value of the second metal.

$\mathrm{Cf}_{\mathrm{k}}=$ concentration value of the $\mathrm{k}^{\text {th }}$ metal.

Similarly, PAHs Pollution Index $(\mathrm{PPI})=\left(\mathrm{Ch}_{1} \mathrm{X} \mathrm{Ch}_{2}\right.$ ....... $\left.\mathrm{Ch}_{\mathrm{K}}\right)^{1 / \mathrm{K}}$,

Where;

$\mathrm{Ch}_{1}=$ concentration value of the first PAH.

$\mathrm{Ch}_{2}=$ concentration value of the second $\mathrm{PAH}$.

$\mathrm{Ch}_{\mathrm{k}}=$ concentration value of the $\mathrm{k}^{\text {th }} \mathrm{PAH}$.

Statistical analysis

All data obtained were subjected to one-way Analysis of Variance (ANOVA) - a parametric statistic - to test significance of differences between site means for the pollutants. Statistical analysis was done using
Analysis Toolpak software, with significance based on an of 0.05 .

\section{RESULTS}

The results of measured values obtained for the standard reference material (PACS-2) for the representative metals, which validated the experimental procedures used for the chemical analyses are shown in Table 1. Mean concentrations of the trace metals and PAHs detected in the sediments are presented in Tables 2 and 3. The MPI and PPI are illustrated in Figs. 2 and 3 respectively. Mean concentrations at each sampling site were calculated from the concentration levels obtained for the study period.

The mean level of Fe in the sediments was 5160.7 $45.08 \mathrm{mg} / \mathrm{g}$ dry weight. The concentration levels of Fe from Agbia/Nedugo, Ogboloma, Koroama, Okolobiri and Polaku were 5148.0-49.9, 5155.7-31.07, 5168.8 -52.46, $5161.3-46.48$ and 5169.7-44.85 mg/g dry weights. Mn was the second most abundant in the sediments. The mean $\mathrm{Mn}$ levels in the sediments varied from 256.64$159.7 \mathrm{mg} / \mathrm{g}$ dry weight at Polaku to 266.92-287.22 mg/g dry weights at Agbia/Nedugo respectively. The metals with lower mean concentrations in the sediments were: Cd (3.0342-61 mg/g dry weight), Cr (3.0228 mg/g dry weight), $\mathrm{Co}$ (9.4386 mg/g dry weight), $\mathrm{Pb}(119.632-269.7$ mg/g dry weight), Ni (9.0824 -7.17 mg/g dry weight) and Zn (113.158-105.59 mg/g dry weight). 


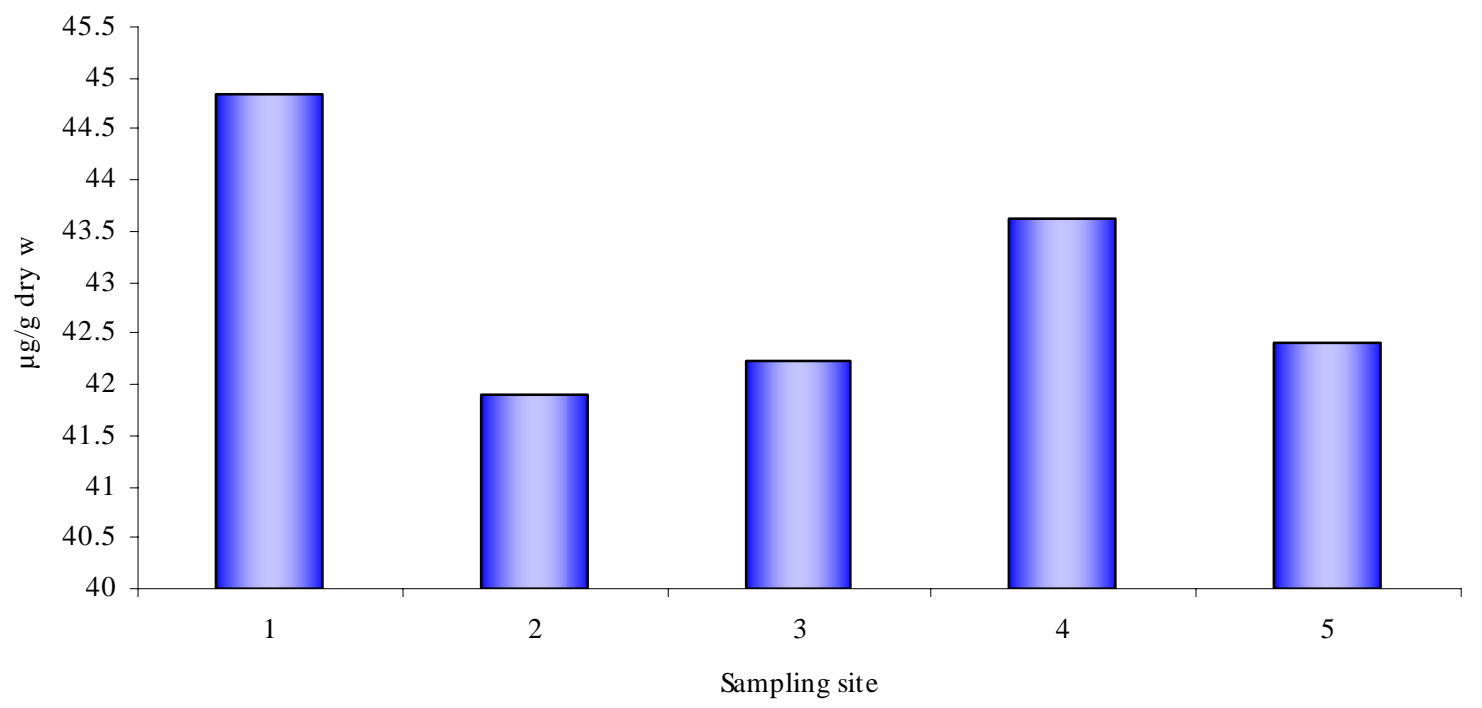

Fig. 2. Metal pollution index (MPI) for each sampling site

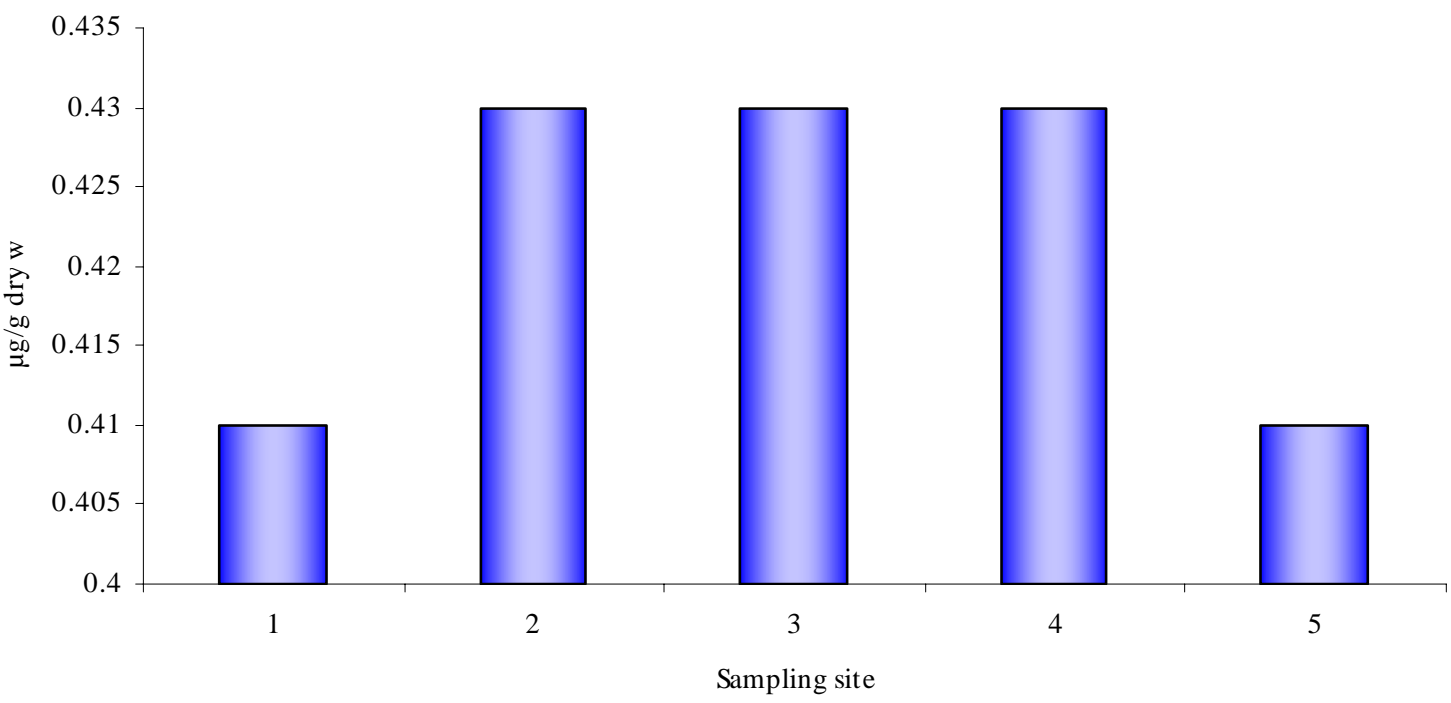

Fig. 3. Mean PAHs pollution index (PPI) for each sampling site

All Taylor Creek sediments analysed contained low molecular weight PAHs. The total concentrations of 5 PAHs, including parent and an alkylated compound, ranged from 152.8-0.007 to 1057.0-0.044 mg/g-wet weight. The highest concentrations were observed at Ogboloma and Okolobiri respectively.

\section{DISCUSSION AND CONCLUSION}

The preliminary assessment of trace metals and PAHs in the sediments of Taylor Creek reflected the degree of pollutant immobilization in the sediments. This is because sediment pollution is considered by many regulatory agencies to be one of the largest risks to the aquatic environment since many aquatic organisms spend the major portion of their lifecycle living on or in sediments (Alam and Sadiq. 1993).

For the eight metals studied in the surface sediments (Cd, Cr, Co, Fe, Pb, Ni, Mn and Zn), significant differences were not established among site means $(\mathrm{P}>0.05)$. This may be due to similarity in physical conditions, particle composition and organic matter between the sites. Figure 2 illustrates the fact that the MPI of the sediments at Agbia/Nedugo was higher than that of the other sites. The highest concentration levels of $\mathrm{Cd}$ and $\mathrm{Zn}, \mathrm{Cr}, \mathrm{Co}, \mathrm{Mn}$ and $\mathrm{Ni}$, and Fe were recorded at Ogboloma, Koroama, Agbia/Nedugo, 
Polaku respectively. Although, it is apparent that the concentration levels of the metals may be due, partly, to catchments in-washings (Ibok, et al., 1989), oil industry activities are also implicated in the region (Nwadinigwe and Nwaorgu, 1999). Further, the sites are located in the lower reaches of Taylor Creek suggesting that the cumulative effect of input from Etelebou Creek, a tributary of Taylor Creek, may be an influencing factor of trace metal pollution. In spite of the levels of trace metals in the sediments, we can deduce that the sediments presented concentrations that were at the Persaud, et. al. (1992) Severe Effect Level and may cause adverse biological effects except for $\mathrm{Cr}, \mathrm{Ni}$ and $\mathrm{Zn}$ respectively.

Furthermore, the Cd levels obtained in this study are lower than the reported values for the sediments of Warri River and its tributaries (Ezemonye and Egborge, 1992). Although Cd presented a low level in this study, it is very toxic to both aquatic and terrestrial organisms even at low concentrations (Kennish, 1992). This is because dissolved Cd has acute $\mathrm{LC}_{50}$ values as low as $3.5 \mathrm{mg} / \mathrm{l}$ in planktonic organisms (Verseeg and Giesy, 1986). In addition, Cd is a sulphur seeking metal that tends to precipitate in anoxic sediments. Experiments carried out at concentrations lower than the values found in this study also show that $\mathrm{Cd}$ can be assimilated from anoxic sediments with high organic matter content (Muniz, et al., 2004), which generates the potential for bioaccumulation through dietary uptake.

The levels of $\mathrm{Pb}$ in the sediments were significantly high when compared with Pb levels in the sediments of Mombassa River, Kenya (Williams, et al., 1997) but correlate positively with that of Antarctic sediments (Alam and Sadiq, 1993). And also, $\mathrm{Pb}$ in the environment is of concern because it is a cumulative poison in humans, and is toxic to many aquatic organisms at low concentrations (Hart, 1982). When released into the environment it has a long residence time compared with most other pollutants. It has low solubility and does not experience microbial degradation. For these two reasons, $\mathrm{Pb}$ has the potential to remain accessible within the sediments and consequently, aquatic food chains far into the future (Davies, 1990). Specifically, the highest concentrations of $\mathrm{Pb}$ found in the current study were at Okolobiri. Whether the levels found are a threat is dependent on a number of factors. For example, certain water chemistry parameters of the aquatic system, such as $\mathrm{pH}$ and oxygen levels, would control the rate of adsorption and desorption of $\mathrm{Pb}$ to and from the sediments (Danulat, et al., 2002).

In a study of trace metal pollution in the sediments of the Niger Delta, Kakulu and Osibanjo (1988) reported $\mathrm{Zn}$ levels that were significantly lower than the levels returned in this study. However, the levels of $\mathrm{Zn}$ in the sediments were positively correlated to $\mathrm{Zn}$ levels in the sediments of the Antartic aquatic ecosystem (Andrade, et al., 2001). This suggests that the levels of $\mathrm{Zn}$ in the sediments of Taylor Creek were high. For Zn metal, the highest levels were found at Ogboloma, thus relating the likely source of this pollutant to the Etelebou Flow Station, which discharges liquid effluents into Etelebou Creek, a tributary of Taylor Creek. This is because Ogboloma is by the outer edge of Etelebou Creek. It is also noteworthy that $\mathrm{Zn}$ is an essential trace element for both flora and fauna (Kiekens 1990). However, exposure to either deficient or high levels can have deleterious effects on an organism's health (Kiekens 1990).

The sampling results also revealed high levels of cobalt throughout the sites. The levels of Co in the sediments were significantly high when compared with Co levels in the sediments of Mombasa River of Kenya (Williams, et al., 1997). Manganese has not been noted to be troublesome as it is often precipitated from surface waters in the presence of oxygen (Ajiwe, et al., 2000). The levels returned in this study were higher than the reported values of Warri River and its tributaries (Ezemonye, 1992) and compare significantly with $\mathrm{Mn}$ levels in the sediments of the Antarctic aquatic ecosystem (Alam and Sadiq, 1993). Levels of Fe for Taylor Creek exceeded those for the Antartic aquatic ecosystem (Andrade, et al., 2001). While noteworthy, these values are not of concern, as a proportion of Fe in sediments may be due to natural erosion (Boggs, 1987).

The levels of $\mathrm{Ni}$ also showed a consistent distribution in Taylor Creek. The natural sources of this element are ferromanganese minerals and ferrous sulfides (Muniz, et al., 2004). Average Ni concentrations are $94 \mathrm{mg} / \mathrm{g}$ in igneous rocks and between 2.6 and 29 for different types of sedimentary rocks (Wedepohl, 1971). The levels of Ni obtained were lower than the reported values for sediments in the marina area of Great Athens (Kokovides, et al., 1992).

Chromium has been considered to be a metal with low biogeochemical mobility, which should reduce its toxicity potential (Abel, 1989); however, questions as 
regards its bioavailability through ingested sediments have been raised (Chong and Wong, 2000). The levels of $\mathrm{Cr}$ in this study were low but higher than $\mathrm{Cr}$ levels in the sediments of Bristol Channel, United Kingdom (Bryan and Langston, 1992).

As a general characteristic, the concentrations of allochthonous PAHs in the sediments of Taylor Creek are lower than the moderately to highly PAHs polluted sites worldwide (Tan and Heit, 1981; Baumard, et al., 1988; Meniconi, et al., 2002; Venturini and Tommasi, 2004). However, the values are significantly elevated when compared with typical levels of PAHs found in pristine areas (Cripps, 1994; Baumard, et al., 1998 and Webster, et al., 2001). This implies that the PAHs were in excess of the Overall Apparent Effects Threshold of Long and Morgan (1990) and maybe mutagenic and carcinogenic and may also cause metabolic and behavioural changes in aquatic organisms (Grimmer, 1985). Further, the PPI was highest at Ogboloma, Koroama and Okolobiri (Fig. 3). At Ogboloma and Koroama, the highest concentration levels of anthracene and acenapthylene were obtained in the sediments. At Ogboloma again, the highest values of 2-methylnaphthalene was obtained. And also, the concentration of fluoranthene in the sediments was highest at Koroama and Okolobiri respectively.

\section{REFERENCES}

Abel, P.D., (1989). Water Pollution Biology, Chichester, Ellis Horwood.

Ajiwe, V.I.E., Nnabuike, B.O., Onochie, C.C., Ajibola, V.O., (2000). Surface water pollution by effluents from industries in Nnewi area, Nigeria. J. Appl. Sci., 3 (3), 1265-1280.

AMA (Agencia de Medio Ambiente de Andalucia, Spain), (1992). Determinacion del contenido de pesticides en agues y de metales en organismo vivos (Determining the pesticide content in waters and the metal content in living organisms). Seville, Spain Ed., AMA, 55-67.

Andrade, S., Poblet, A., Scagliola, M., Vodopivez, C., Curtosi, A., Pucci, A., Marcovecchio, J., (2001). Distribution of heavy metals in surface sediments from an Antartic marine ecosystem. Environ. Monitor. Assess., 66, 147-158.

Anonymous, (1990). Microwave assisted acid digestion of aqueous samples and extracts. SW-846.

Method 3015 and 3051. Test methods for evaluating solid waste. Washington, DC: U.S. Environment Protection Agency (EPA).

Alam, I.A., Sadiq, M., (1993). Metal concentrations in Antartic sediment samples collected during the Trans-Antartica 1990 expedition. Marine Pollut. Bull., 26, 523-527.

Andrade, S., Poblet, A., Scagliola, M., Vodopivez, C., Curtosi, A., Pucci, A., Marcovecchio, J., (2001). Distribution of heavy metals in surface sediments from an Antartic marine ecosystem. Environ. Monitor. Assess., 66, 147-158.
Baumard, P., Budzinski, H., Mchin, Q., Garrigues, P., Burgeot, T., Bellocq, J., (1998). Origin and bioavailability of PAHs in the Mediterranean Sea from mussel and sediment records, Estuar. Coast. Shelf Sci., 47, 77 - 90.

Boggs, S., (1987). Principles of sedimentology and stratigraphy. London. Merrill.

Bryan, G.W., Langston, W.J., (1992). Bioavalability, accumulation and effects of heavy metals in sediments with special reference to the United Kingdom estuaries- a review. Environ. Pollut., 76, 89-13.

Cantillo, A., Calder, J., (1990). Reference materials for marine science. Fresenius J. Anal. Chem., 338, 380-382.

Chong, K., Wong, W.X., (2000). Bioavailability of sediment bound $\mathrm{Cd}, \mathrm{Cr}$, and $\mathrm{Zn}$ to the green mussel Perna viridis and Manila clam Ruditapes philippinarum. J. Exp. Mar. Bio. Ecol., 255, 75-92.

Carolyn, S.B., Joy-Elaine, A., Sean, M. B., Katarzyna, C., (2004). Influence of Sediment Characteristics on Heavy Metal Toxicity in an Urban Marsh. Urban Harbitats, 2, 91-111.

Clements, W.H., (1991). Community Responses of Stream Organisms to Heavy Metals: A Review of Descriptive and Experimental Approaches. In Ecotoxicology of Metals: Current Concepts and Applications, pp 363-391. Edited by Newman, M.C. and Mclntosh, A.W. Boca Raton, FL: CRC Press.

Cripps, G.C., (1994). Hydrocarbons in the Antarctic marine environment: monitoring and background, Int. J. Environ. Anal. Chem., 55, 3 - 13.

Danult, E., Muniz, P., Garcia-Alonso, J., Yannicelli, B., (2002) First assessment of the highly contaminated harbour of Montevideo, Uruguay. Mar Pollut Bull, 44, 554-65.

Davies, C.A., Tomlinson, K., Stephenson, T., (1991). Heavy metals in River tees estuary sediments. Environ. Technol., 12, 961-972.

Ezemonye, L.I.N., Egborge E. , (1992). Heavy metals concentration in water, sediment and selected Fish of Warri River and its Tributaries. Proc. National Seminar on petroleum, P.T.I., Effurun. Nigeria. 3, 91-112.

Forstner, U., Wittman, G.T.W., (1983). Metal pollution in the aquatic environment. $2^{\text {nd }}$ Edition. Springer Verlag Publishers, New York. 18-49.

Hendricks, J.P., Meyers, T.R., Shelton, D.W., Casteel, J.L., Bailey, G.S., (1985). Hepatocarcinogenicity of benzo (a) pyrene to rainbow trout by dietary exposure and intraperitoneal injection. J. Natl. Cancer Inst., 74, 839 851.

Ibok, U.J., Udosen, E.D., Udoidiong, O.M., (1989). Heavy metals in fishes from some streams in Ikot Ekpene area of Nigeria. Nig. J. Tech. Res., 1, 61-68.

Kakulu, S.E., Osibanjo, O., (1985). Pollution studies of Nigerian Rivers: Trace metal Levels of surface waters in the Niger Delta Area. Int. J. Environ. Int., 13, 247-251,

Kennish, M.J., (1992). Ecology of estuaries: anthropogenic effects. Marine Science Series. USA: CRC Press

Kokovides, K., Loizidou, M., Moropoulou, T., (1992). Environmental study of the marinas. Part 1. A study on the pollution in the marinas Areas. Env. Technol., 13, 239244.

Laflame, R.E., Hite, R.A., (1978). The global distribution of polycyclic aromatic hydrocarbons in recent sediments, Geochim. Cosmochim. Acta 43, 289-303. 
La Point, T.W., Melancan, S.M., Morris, M.I., (1984). Relationships, Among Observed Metal Concentrations, Criteria, and Benthic Community Structural Responses in 15 Streams. J. Wat. Pollut. Con. Federation, 56, 1030-1038.

Long, E.R., Morgan, L.G., (1990). The Potential for Biological Effects of Sediment-Sorbed Contaminants tested in the National States and Trends Program. National Oceanic Atmospheric Administration (NOAA) Technical Memorandum No. 5, OMA52, NOAA National Ocean Service, Seattle, Washington.

German Ministry of Environment, (1993). Environmental sample bank. Annual report 1991. Berlin, 139 (Report No. UBA-7/93) in German.

McConchie, D.M., Mann, A.W., Lintern, M.J., Longman, D., Talbot, V., Gabelish, A., (1988). Heavy metals in marine biota, sediments and waters from the Shark Bay area, Western Australia. J. Coast. Res., 4, 37-58.

Meniconi, M.F.G., Gabardo, I.T., Carneiro, M.E.R., Barbanti, S.M., Silva, G.C. , Massone, C.G., (2002). Brazillian oil spills chemical characterization - case studies, Environ. Forensics, 3, 303-321.

Muniz, P., Danulat, E., Yannicelli, B., Garcia-Alonso, J., Medina, G., Bicego, M.C., (2004). Assessment of contamination by metals and petroleum hydrocarbons in sediments of Montevideo Harbour (Uruguay). Environ. Int., 29, 1019-1028.

Neff, J.M., (1979). Polycyclic aromatic hydrocarbons. Sources, fates and biological effects (Applied Science Publishers, London, UK).

Nriagu, J.O., (1996). A history of global metal pollution. Science, 272, 191-214.

Nwadinigwe, C.A., Nwaorgu, O.N., (1999). Metal contaminants in some Nigerian Well-Head Crudes: Comparative Analysis. J.Chem. Soc. Nigeria, 24, 118-121.

Okafor, E.C., Opuene, K., (2006). Correlations, partitioning and bioaccumulation of trace metals between different segments of Taylor Creek, southern Nigeria. Int. J. Environ. Sci. Tech., 3 (4), 437-445.

Persaud, D. Jaagumagi, R., Hayton, A., (1992). Guidelines for the protection and Management of Aquatic Sediment Quality in Ontario. Ontario Ministry of the Environment, Queen's Printer for Ontario.

Simoneit, B.R.T., (1986). Characterization of organic constituents in aerosols in relation to their origin and transport: a review, Int. J. Environ. Anal. Chem., 23, 207 237.

Tan, Y.L. , Heit, M., (1981). Biogenic and abiogenic polynuclear aromatic hydrocarbons in sediments from two remote Adirondack lakes, Geochim. Cosmochim. Acta, 45, 2267 2279.

Usero, J.; Gonzalez-Regalado, E., Gracia, I., (1996). Trace metals in the bivalve mollusc Chamelea gallina from the Atlantic coast of southern Spain. Mar. Pollut. Bull., 32, 305-310.

Venturini, N., Tommasi, L.R., (2004). Polycyclic aromatic hydrocarbons and changes in the trophic structure of polychaete assemblages in sediments of Todos os Santos Bay, Northeastern, Brazil, Mar. Pollut. Bull. , 48, 97 - 107.

Versteeg, D.J., Giesy, J.P., (1986). The histological and biochemical effects of cadmium exposure in the bluegill sunfish (Lepomis macrochirus). Ecotoxicol. Environ. Saf., 11, 31-43.

Webster L., Fryer, R.J., Dalgarno, E.J., Megginson, C. and Moffat, C.F., (2001). Polycyclic aromatic hydrocarbons and geochemical biomarker composition of sediments from voes and coastal areas in the Shetland and Orkney Islands, J. Environ. Monit. 3, 591 - 601.

Wedepohl, K.H., (1971). Geochemistry. New York: Holt, Rhinehart and Winston

Williams, T.M., Rees, J.G., Ferguson, A., Herd, R.A., Kairu, K.K., Yobe, A.C., (1997). Metals, petroluem hydrocarbons and organochlorines in inshore sediments and waters of Mombasa, Kenya. Marine Pollut. Bull., 34, 570-5.

\section{AUTHOR (S) BIOSKETCHES}

Okafor, E. Ch., Ph.D., is a lecturer in the Department of Pure and Industrial Chemistry, University of Nigeria, Nsukka, Nigeria. Email: ecokafor12@yahoo.com

Opuene, K., M.Sc., Ph.D., was a Ph.D. research student in Analytical Chemistry at the University of Nigeria, Nsukka, Nigeria. Email: opuenekings@yahoo.com

This article should be referenced as follows:

Okafor, E. Ch., Opuene, K., (2007). Preliminary assessment of trace metals and polycyclic aromatic hydrocarbons in the sediments. Int. J. Environ. Sci. Tech., 4 (2), 233-240. 